\title{
extradenticle determines segmental identities throughout Drosophila
}

\section{development}

\author{
Cordelia Rauskolb1, Katherine M. Smith², Mark Peifer ${ }^{2}$ and Eric Wieschaus ${ }^{1}$ \\ ${ }^{1}$ Department of Molecular Biology, Princeton University, Princeton, NJ 08544, USA \\ ${ }^{2}$ Department of Biology, University of North Carolina, Chapel Hill, NC 27599, USA
}

\section{SUMMARY}

extradenticle (exd) and the homeotic selector proteins together establish segmental identities by coordinately regulating the expression of downstream target genes. The inappropriate expression of these targets in exd mutant embryos results in homeotic transformations and aberrant morphogenesis. Here we examine the role of $\mathrm{exd}$ in adult development by using genetic mosaics and a hypomorphic exd allele caused by a point mutation in the homeodomain. exd continues to be essential for the specification of segmental identities, consistent with a continuing requirement for $e x d$ as a cofactor of the homeotic selector proteins. Loss of exd results in the homeotic transformation of abdominal segments to an A5 or A6 segmental identity, the antenna and arista to leg, and the head capsule to dorsal thorax or notum. Proximal leg structures are particularly sensitive to the loss of $e x d$, although $e x d$ does not affect the allocation of proximal positional values of the leg imaginal disc. Using heat-shocks to induce expression of a $h$ sp 70-exd fusion gene, we show that, in contrast to the homeotic selector genes, ubiquitously high levels of exd expression do not cause pattern abnormalities or segmental transformations.

Key words: extradenticle, homeotic transformation, clonal analysis, Drosophila, pattern formation, leg development

\section{INTRODUCTION}

In Drosophila, development occurs in two distinct phases, an embryonic period that leads to the larva and a period of imaginal development that gives rise to the adult. Both the larval and adult body patterns are segmented. Homeotic genes of the Antennapedia (ANT-C) and bithorax (BX-C) complexes specify segmental identities throughout both phases of development (reviewed by Duncan, 1987; Kaufman et al., 1990). Each homeotic selector gene is expressed in a distinct spatial and temporal pattern. If a given homeotic gene is absent or is expressed outside its normal domain, the morphology of affected segments is altered to reiterate that of other segments. The homeotic selector genes encode homeodomain-containing transcription factors that specify different developmental fates by regulating the expression of distinct sets of downstream genes (reviewed by Botas, 1993).

We have shown that extradenticle (exd) plays an important and singular role in regulating homeotic gene activity (Peifer and Wieschaus, 1990a; Rauskolb et al., 1993; Rauskolb and Wieschaus, 1994). exd mutant embryos show homeotic transformations, although the ANT-C and BX-C genes are expressed normally and function genetically in the appropriate segments. Instead, in exd mutants the activity of the homeotic selector genes is altered, resulting in aberrant morphology. In the visceral mesoderm, exd and the homeotic selector genes coordinately regulate some of the same target genes (Rauskolb and Wieschaus, 1994). In the absence of exd the homeotic proteins are incapable of regulating these targets. exd also encodes a homeodomain protein and thus the requirements for exd activity may reflect a direct interaction between exd and the selector proteins on the target DNA (Rauskolb et al., 1993). Indeed, in vitro studies have demonstrated cooperative interactions between exd and Ultrabithorax and exd and abdominal-A (Chan et al., 1994; van Dijk and Murre, 1994). Together, these experiments suggest that exd is a ubiquitous cofactor required in the embryo for the interaction of various homeodomain proteins with many of their targets.

Given the dramatic effect of exd on selector gene activity in the embryo, it was important to determine whether exd is also required to specify segmental identities at post-embryonic stages of development. Because null alleles of exd are embryonic lethal, we used genetic mosaics to investigate the requirements for exd function at later stages of development. We extended this analysis to whole animals and developing discs, using a hypomorphic allele whose larval lethality was circumvented by increased wild-type dosage in the mother. Lastly, we used heat-shock constructs to determine whether ubiquitous expression of exd is sufficient to alter cell fates. These experiments demonstrate that exd, like the homeotic selector genes, is required for the specification of segmental identities throughout development.

\section{MATERIALS AND METHODS}

\section{Fly stocks}

exd mutants are described by Wieschaus et al. (1984) and by Katzen 
(1990). The following enhancer trap lines were used: $r K 111$ (insertion in odd-skipped; Cohen, 1993), rK568 (insertion in apterous; Cohen et al., 1992), and $P\left(L a c, r y^{+}\right) A R 30 b$ (insertion in teashirt; Fasano et al., 1991). Balancer chromosomes and all other mutants are described by Lindsley and Zimm (1992).

\section{Generation and analysis of exd mosaic flies}

To produce exd gynandromorphs, heterozygous $y$ w exd $d^{X P 11} f / F M 6$ or $y$ w exd EM5 f/FM6 females were crossed to $\operatorname{In}(1) w^{v C} / Y$ males. All female progeny surviving to adulthood were scored as either exd or FM6, mosaic or nonmosaic (Table 1). To assess mosaic frequency in the FM6 controls, clones were identified on the basis of male phenotypic characteristics in $\mathrm{XO}$ clones. The frequency of male structures in controls ranged from $39 \%$ in the first thoracic legs to $25.5 \%$ in the analia; the average was $30.7 \%$. Since the distribution of XO clones is random, the clone frequency in any given structure is about $30 \%$, similar to that seen in previous experiments (Wieschaus et al., 1992). Mitotic clones of exd were produced as described by Wieschaus et al. (1992) except females of the genotype $y w$ exd $d^{X P 11} f / F M 6$ or $y w$ exd ${ }^{E M 5} \mathrm{f} / F M 6$, or in controls $y w f / y w f$, were crossed to $M(1) O^{s p} / Y$ males.

\section{Sequencing of mutant alleles}

DNA was isolated from homozygous mutant embryos $\left(e x d^{X P 11}\right.$, exd $^{Y O 12}$, exd $d^{E M 25}$, exd $d^{E M 54}$, exd $\left.d^{W M}\right)$, heterozygous adults $\left(\right.$ exd $^{E M 52}$ ) $e x d^{W M}$ and $\left.e x d^{E M 5} / F M 7 e x d^{+}\right)$, or homozygous mutant larvae $\left(e x d^{E M 5}\right)$ and the exd coding region was PCR amplified as described by Peifer and Wieschaus (1990b). Amplified DNA was cloned into pGEM-T (Promega). At least three independent clones were sequenced for each allele, and in most the entire coding region. A silent nucleotide polymorphism allowed the $E M$ series of mutants to be distinguished from $F M 7$, allowing unambiguous identification of clones encoding the mutant allele. A silent polymorphism at nt 1184 confirmed that $e x d^{X P 11}$ and $e x d^{E M 25}$ are independently derived.

\section{HS:exd expression constructs and heat-shocks}

Three HS:exd constructs with different 3' UTRs were made; details available upon request. $H S:$ exdl contains the exd coding region and hsp70 $3^{\prime}$ untranslated sequences. HS:exd2 is identical to HS:exd1, but has about $400 \mathrm{bp}$ of untranslated $3^{\prime}$ exd sequences added. $H S: \operatorname{exd} 3$ is similar to $H S: \operatorname{exd} 2$, but contains the poly(A) tail of $U b x$. Transgenic flies were generated as described by Rauskolb et al. (1993). The HS:exd1-4AX transgene, on the $\mathrm{X}$ chromosome, and autosomal lines HS:exd2-7A and HS:exd3-9A are homozygous viable. To assay for rescue of exd mutant embryos, the HS:exd1$4 \mathrm{AX}$ transgene was recombined with a chromosome carrying $\operatorname{exd}^{X P 11}$ to generate the stock $w$ HS:exd1-4AX $\operatorname{exd}^{X P 11 / F M 7 /}$ $D p(1 ; Y) s h i^{+} Y \# 1$.

Six different lines carrying HS:exdl were heat-shocked for 1 hour at $37^{\circ} \mathrm{C}$. Development continued at room temperature. Ages tested were 0-19, 19-42.5, 42.5-69 hours and 2.9-4.6, 4.6-6.5, 6.5-7.8 days. No differences in phenotype or viability were noted between transformant lines and $w$ controls. Other treatments in which several lines each carrying HS:exd1, HS:exd2, or HS:exd3, hemizygous or homozygous, were tested included the following: 0- to 3-day old animals were heat-shocked for 1 hour at $37^{\circ} \mathrm{C}$ every 24 hours until eclosion; white pupae were heat-shocked twice daily for 1 hour at $37^{\circ} \mathrm{C}$; and, to induce persistent exd expression, white pupae were placed at $33^{\circ} \mathrm{C}$ for 5 days. HS: exd flies did not display any developmental abnormalities under any of these conditions.

\section{Detection of expression patterns}

Whole-mount in situ hybridizations were carried out as described by Rauskolb et al. (1993). Imaginal discs from male $\left(e x d^{E M 5}\right)$ and female $\left(\operatorname{exd}^{+}\right)$mature third instar larvae were dissected and $\beta$-galac- tosidase expression patterns determined as described by Irvine et al. (1991).

\section{RESULTS}

\section{Uniform expression of exd+ suppresses the phenotype of null mutations}

The homeotic transformations produced by loss of zygotic exd are most obvious in the anterior two-thirds of the embryo (Wieschaus et al., 1984; Peifer and Wieschaus, 1990a). The head is defective and thoracic segments T2 and T3 are transformed anteriorly toward $\mathrm{T} 1$. The abdominal segments are transformed posteriorly; segments A1 through A4 are transformed toward A5. The most posterior abdominal segments

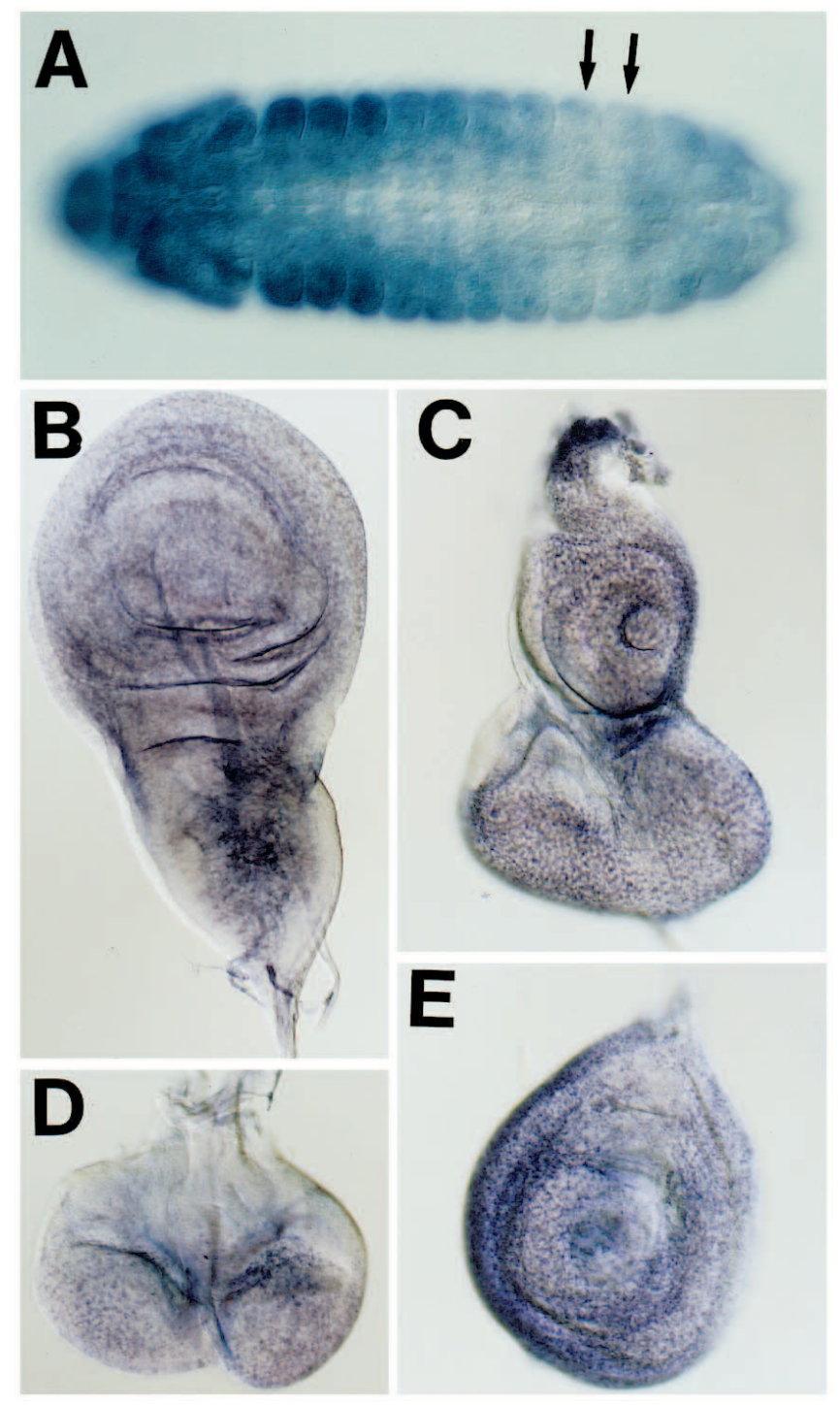

Fig. 1. exd is uniformly expressed in imaginal discs. exd RNA expression at mid-embryogenesis and in imaginal discs as revealed by whole-mount in situ hybridization. (A) Wild-type embryo at stage 13 demonstrating that exd is expressed at a distinct level in each segment. Lowest levels of expression are observed in segments A5 and A6 (arrows). exd expression is uniform in (B) wing, (C) eyeantennal, (D) genital, and (E) leg imaginal discs. 

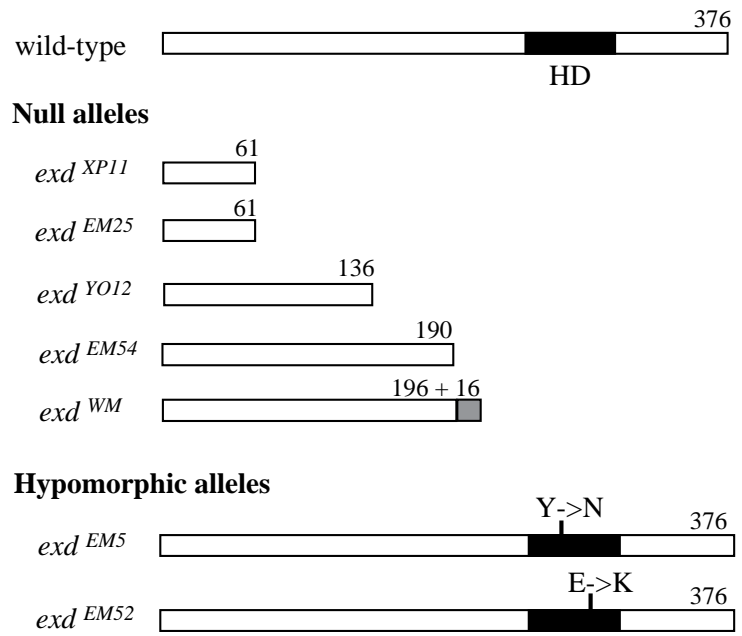

Fig. 2. Molecular analysis of exd alleles. The bar schematically represents the 376 amino acid exd protein, including the homeodomain (HD). Null alleles have the following lesions: $\operatorname{exd}^{X P 11} \mathrm{nt}$ (nucleotide) $390 \mathrm{C} \rightarrow \mathrm{T}$; $\operatorname{exd}^{E M 25} \mathrm{nt} 390 \mathrm{C} \rightarrow \mathrm{T}$; $\operatorname{exd}^{Y O 12} \mathrm{nt}$ $615 \mathrm{C} \rightarrow \mathrm{T} ; e^{e x d^{E M 54}} \mathrm{nt} 777 \mathrm{C} \rightarrow \mathrm{T} ; e^{2 x d^{W M}}$ deletes the region from $\mathrm{nt}$ 36 of the intron $790 / 791$ to nt 813 . This last lesion results in a frameshift, adding 16 novel amino acids after amino acid 196. All null mutations introduce a premature stop codon, thereby giving rise to a truncated protein of the indicated length. Hypomorphic exd $d^{E M 5}$ alters nt 978 from $\mathrm{T} \rightarrow \mathrm{A}$ and $e x d^{E M 52}$ alters nt 1008 from $\mathrm{G} \rightarrow \mathrm{A}$. These result in missense mutations within the homeodomain, as indicated. We have also now sequenced exd genomic DNA. The exd gene has three small introns at nts $471 / 472$, 790/791, and 1049/1050. All contain multiple stop codons, and using consensus acceptor and donor sites, no likely alternate splice possibilities are apparent. The region C-terminal to the homeodomain does not contain any introns, ruling out the possibility that exd is alternatively spliced in a manner similar to the vertebrate homologs $p b x 1$ and $p b x 3$ (Monica et al., 1991).

and telson are normal. These transformations are somewhat reminiscent of the modulated pattern of zygotic exd expression during mid-to-late embryonic stages (Fig. 1A; Rauskolb et al., 1993). High levels of exd transcripts are observed in the head and thoracic segments, while levels decline posteriorly; the lowest levels are observed in A5 and A6.

The homeotic transformations described above are produced by deletions and apparently amorphic alleles at the locus (Peifer and Wieschaus, 1990a). Sequence analysis of five such alleles reveals lesions consistent with their amorphic nature; $e x d^{X P 11}$, exd $d^{Y O 12}$,exdEM25, exd $d^{E M 54}$, and $e x d^{W M}$ result from the introduction of a premature stop codon or a frameshift that truncates the protein before the homeodomain (Fig. 2).

The mutants $e x d^{E M 5}$ and $e x d^{E M 52}$ are not embryonic lethal. We have examined $\operatorname{exd} d^{E M 52}$ in trans to the null alleles $e x d^{X P 11}$ and $e x d^{W M}$. exdEM52/exdX11 animals die as pharate adults with no obvious cuticular defects, while exd ${ }^{E M 52} / e x d^{W M}$ animals sometimes eclose as morphologically normal adults, but always die within a day or two. Transheterozygotes of the two embryonic viable alleles, exd $\operatorname{ex}^{E M} / \operatorname{exd} d^{E M 52}$, survive to adulthood at about $25 \%$ the frequency of their $\operatorname{exd}^{E M 5} / F M 7$ siblings, but often die within 24 hours. Minor cuticular defects, including an absence of coxal bristles on the mesothorax and missing or reduced palps, occur. Sequence analysis of these two hypomorphic alleles revealed that they each carry a missense mutation in the homeodomain (Fig. 2). Both mutations occur in residues that are not part of the global homeodomain consensus, but which are conserved between exd and its vertebrate homologs (Rauskolb et al., 1993).

The embryonic cuticular phenotypes associated with exd null alleles are observed only in embryos from heterozygous mothers; embryos derived from attached-X mothers, which carry two wild-type copies of exd, die with a normal cuticular pattern (Wieschaus and Noell, 1986). Because maternally supplied exd RNA is uniformly distributed in the egg, we have argued that a particular spatial pattern of exd expression is irrelevant for rescuing activity, and thus the distribution of exd itself does not appear to provide positional information (Rauskolb et al., 1993). To test this view, we used the $h s p 70$ promoter to drive ubiquitous zygotic expression of exd. Three HS: exd constructs, differing in their 3' UTRs (see Materials and Methods), rescue exd null embryos to almost normal morphology following a single heat-shock at the onset of gastrulation (Fig. 3). Notably, ectopic exd expression has no obvious effect on the development of wild-type embryos.

These results raise questions about the significance of the modulated expression pattern of exd that arises during midembryogenesis. This late expression pattern may reflect a requirement for exd during post-embryonic stages of development. Northern analysis indicated that exd is expressed at all stages of development (Rauskolb et al., 1993). Furthermore, in situ hybridization to imaginal discs from mature third instar larvae reveals that exd is expressed uniformly in the eyeantennal, leg, wing, haltere, and genital discs (Fig. 1). Thus, the patterned exd expression in the late embryo may mark the beginning of a later role for exd in specifying the segmental identities of adult structures.

\section{exd mosaics survive to adult stages but with reduced viability}

To analyze post-embryonic requirements for exd, we generated gynandromorph mosaics in which the male exd mutant regions of the adult cuticle were marked with yellow $(y)$ and forked $(f)$. The survival of these exd mosaic flies was greatly reduced. When an amorphic allele $\left(e x d^{X P 11}\right)$ was used, exd mosaics were recovered at only $18 \%$ of the control FM6

Table 1. Recovery of exd gynandromorphs surviving to adulthood

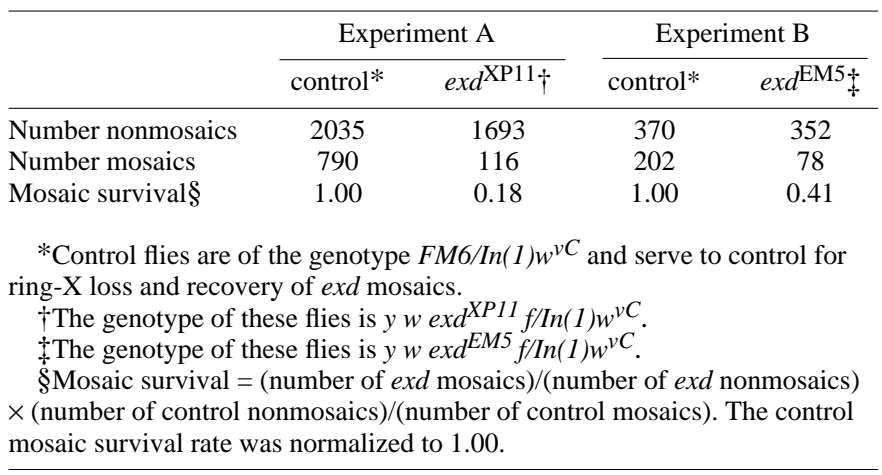


Table 2. Frequencies of $\operatorname{exd}^{X P 11}$ and $e x d^{E M 5}$ clones in various structures of surviving adult gynandromorphs

\begin{tabular}{|c|c|c|c|c|}
\hline Structure & $\begin{array}{l}\text { No. exd }{ }^{X P 11} \\
\text { clones/ } \\
\text { no. times } \\
\text { scored }\end{array}$ & $\begin{array}{l}\text { Frequency of } \\
\quad \operatorname{exd}^{X P 11} \\
\text { clones } \\
(\%)^{*}\end{array}$ & $\begin{array}{l}\text { No. } \text { exd }^{E M 5} \\
\text { clones/ } \\
\text { no. times } \\
\text { scored }\end{array}$ & $\begin{array}{l}\text { Frequency of } \\
\text { exd } \\
\text { clones } \\
\quad(\%)\end{array}$ \\
\hline \multicolumn{5}{|l|}{ Head } \\
\hline $\mathrm{pv} \dagger$ & $3 / 232$ & 1.3 & $25 / 154$ & 16.2 \\
\hline Ocellar $\dagger$ & $2 / 232$ & 0.9 & $26 / 156$ & 16.7 \\
\hline Postorbital† & $0 / 232$ & 0.0 & $27 / 154$ & 17.5 \\
\hline Antenna & $8 / 232$ & 3.4 & $27 / 156$ & 17.3 \\
\hline Palpus & $1 / 231$ & 0.4 & $20 / 152$ & 13.2 \\
\hline Proboscis & $3 / 232$ & 1.3 & $18 / 156$ & 11.5 \\
\hline \multicolumn{5}{|l|}{ Thorax } \\
\hline pst $\dagger$ & $1 / 227$ & 0.4 & $2 / 155$ & 1.3 \\
\hline Humerus & $5 / 226$ & 2.2 & $8 / 154$ & 5.2 \\
\hline Scutellum & $1 / 227$ & 0.4 & $3 / 155$ & 1.9 \\
\hline anp $\dagger$ & $1 / 227$ & 0.4 & $2 / 155$ & 1.3 \\
\hline Wing & $0 / 228$ & 0.0 & $4 / 158$ & 2.5 \\
\hline $\mathrm{sp} \dagger$ & $2 / 230$ & 0.9 & $0 / 151$ & 0.0 \\
\hline T1 leg & $5 / 230$ & 2.2 & $12 / 155$ & 7.7 \\
\hline T2 leg & $4 / 232$ & 1.7 & $7 / 156$ & 4.5 \\
\hline T3 leg & $5 / 230$ & 2.2 & $12 / 156$ & 7.7 \\
\hline \multicolumn{5}{|l|}{ Abdomen } \\
\hline A1 tergite & $13 / 232$ & 5.6 & $9 / 155$ & 5.8 \\
\hline A2 tergite & $29 / 232$ & 12.5 & $25 / 156$ & 16.0 \\
\hline A3 tergite & $40 / 230$ & 17.4 & $31 / 156$ & 19.9 \\
\hline A4 tergite & $50 / 231$ & 21.6 & $36 / 155$ & 23.2 \\
\hline A5 tergite & $48 / 224$ & 21.4 & $29 / 156$ & 18.6 \\
\hline A6 tergite & $52 / 226$ & 23.0 & $28 / 156$ & 17.9 \\
\hline A7 tergite & $36 / 217$ & 16.6 & $26 / 156$ & 16.7 \\
\hline Genitalia & $30 / 232$ & 12.9 & $21 / 154$ & 13.6 \\
\hline Analia & $37 / 232$ & 15.9 & $19 / 154$ & 12.3 \\
\hline \multicolumn{5}{|c|}{$\begin{array}{l}\text { *The frequency of clones in the } F M 6 \text { control gynandromorphs was about } \\
30 \% \text { for any given structure. } \\
\nmid \text { These structures are particular bristles. pst, presutural; pv, postvertical; } \\
\text { anp, anterior notopleural; sp, sternopleura. } \\
\text { For a description of adult cuticular structures see Bryant (1978). }\end{array}$} \\
\hline
\end{tabular}

frequency, while with the hypomorphic allele $\operatorname{exd}{ }^{E M 5}$ the mosaic survival was $41 \%$ (Table 1). The viability of mosaics depended on the distribution of exd mutant tissue (Table 2). In the surviving $e x d^{X P 11}$ mosaics, exd cells were seldom obtained in the head and thorax. By contrast, the frequencies of $\mathrm{exd}^{-}$patches in the abdomen and genitalia (5.6\% to 23\%) were closer, although still below, control frequencies (30\%; Table 2). Similar results were obtained with exd ${ }^{E M 5}$, except that structures were more often $e^{-}$, particularly in the head (Table 2).
The low recovery of $e x d^{-}$cells in adult head and thoracic structures presumably reflects a higher requirement for exd in the regions of the embryo giving rise to these structures. Given the large size of the exd clones in gynandromorphs, the focus of this lethality need not be the head or thoracic disc precursors themselves; it could be the central nervous system or another internal tissue. When mitotic recombination is used to produce smaller, later clones restricted to individual discs, the recovery of exd cells in the head and thorax increases, but is still reduced (Table 3). Most of the reduction in clone frequency in the mitotic recombination experiments can be attributed to the failure to obtain clones in certain regions of each disc. Moreover, recovered clones were frequently associated with transformations of segmental identity (see below). Thus, although not required for the viability of most imaginal cells, exd does play an essential role in the development of adult structures.

\section{Loss of exd leads to homeotic transformations in the adult abdomen}

The abdominal segments are distinguished by unique features of the tergites (dorsal cuticle). The A1 tergite has small bristles; the A5 and A6 tergites have uniform pigmentation in males; the A5 tergite has trichomes (fine hairs) of characteristic density; the A6 tergite essentially lacks trichomes; and the A7 tergite is small and dumbbell-shaped (Bryant, 1978; Karch et al., 1985; Sanchez-Herrero et al., 1985). Homeotic transformations were associated with exd clones in both gynandromorph and mitotic recombination experiments. In exd ${ }^{X P 11}$ mosaic flies, the segmental identity of clones in A1 through A4 is transformed posteriorly toward A5 or A6. In gynandromorphs, this transformation is evidenced by the darker cuticle pigmentation and trichome density characteristic of posterior segments (Fig. 4). Most often these clones have a trichome density characteristic of A5. However, clones were also recovered with regions devoid of trichomes, indicative of a partial transformation toward A6. The clones behave cell autonomously, as only cells marked with $y$ and $f$ are transformed. exd also affects tergite differentiation less specifically. Small exd $d^{X P 11}$ clones within a tergite differentiated normally, but larger clones encompassing most or all of a hemitergite often differentiate abnormally, resulting in the absence of part of the tergite.

In contrast to the posterior transformations associated with clones in $\mathrm{A} 1-\mathrm{A} 4$, exd ${ }^{X P 11}$ clones within $\mathrm{A} 6$ and $\mathrm{A} 7$ are transformed anteriorly. Clones within A6 are transformed toward A5 as evidenced by the presence of trichomes, which are not

Table 3. Frequency of $\operatorname{exd}$ mitotic clones in various adult structures

\begin{tabular}{|c|c|c|c|c|c|c|c|}
\hline & Head & Humerus & Wing & Tergites & Sternites & Genitalia & Analia \\
\hline \multirow[t]{2}{*}{$y w f$} & $\begin{array}{c}0.53 \\
(61 / 116)\end{array}$ & $\begin{array}{c}0.11 \\
(7 / 64)\end{array}$ & $\begin{array}{c}0.19 \\
(12 / 64)\end{array}$ & $\begin{array}{c}3.29 \\
(28 / 8.5)\end{array}$ & $\begin{array}{c}1.22 \\
(11 / 9)\end{array}$ & $\begin{array}{c}0.14 \\
(12 / 84)\end{array}$ & $\begin{array}{c}0.11 \\
(10 / 87)\end{array}$ \\
\hline & $100 \%$ & $100 \%$ & $100 \%$ & $100 \%$ & $100 \%$ & $100 \%$ & $100 \%$ \\
\hline \multirow{2}{*}{$\operatorname{exd}^{X P 11}$} & $(34 / 115)$ & $(2 / 88)$ & $(12 / 88)$ & $(31 / 20)$ & $(3 / 20)$ & $(11 / 87)$ & $(3 / 84)$ \\
\hline & $56 \%$ & $18 \%$ & $74 \%$ & $47 \%$ & $13 \%$ & $89 \%$ & $31 \%$ \\
\hline \multirow[t]{2}{*}{$e x d^{E M 5}$} & 0.70 & 0.06 & 0.24 & 3.53 & 1.00 & 0.14 & 0.10 \\
\hline & $(78 / 111)$ & $(5 / 88)$ & $(21 / 88)$ & $(53 / 15)$ & $(15 / 15)$ & $(10 / 71)$ & $(7 / 72)$ \\
\hline
\end{tabular}

The top value is the frequency at which clones were obtained. Values in parentheses are the actual no. of clones/no. of adults examined. The percentages reflect the frequency of exd clones relative to the frequency of $y w f$ control clones (normalized to $100 \%$ ). 
normally found in the A6 tergite (Fig. 4E). In wild-type flies the A7 tergite is present in females and absent in males. Clones of $e x d^{X P 11}$ in A7 develop in both gynandromorph and mitotic recombination mosaics, even though in gynandromorphs the tissue is male in genotype (Fig. 4E). These ectopic A7 tergites have a morphology characteristic of A5 or A6, indicating that they are transformed anteriorly. The only segment where exd clones have no effect is in A5, where segmental identity remains normal.

The genital disc forms the most posterior structures of the abdomen. Female genital structures are derived from A8, male genitalia from A9, and both male and female analia from A10 (Schüpbach et al., 1978). In wild-type females only A8 and A10 segment derivatives develop, and in males only A9 and A10 develop. exd clones in the female genitalia show the same anterior-ward transformation observed in A6 and A7. The tiny A8 tergite is enlarged and has bristles characteristic of more anterior abdominal tergites (Fig. 5A). The vaginal plate is also abnormal with multiple rows of thornlike bristles and fusions along the midline. Occasionally we also observe an ectopic ninth tergite in females with exd null clones, implying that the normally absent A9 has been transformed to a more anterior fate (Fig. 5B). In the male primordia the effects of exd are more subtle. In gynandromorphs, when the entire genital disc is male and $\mathrm{exd}^{-}$, the genitalia and analia remain as a ball of internalized cuticle and do not fuse with the more anterior abdominal segments, regardless of whether they are wild-type or $\operatorname{exd}^{-}$(Fig. 5C). These unfused male genitalia and analia are apparently normal, including such structures as the clasper, penis and anal plate. When the genitalia of a gynandromorph is composed of both female $e x d^{+}$and male $e x d^{-}$cells, it fuses with the exoskeleton, and the $e x d^{-}$cells make morphologically normal male structures. Clones restricted to the analia are normal in both gynandromorphs and mitotic recombination experiments; exd does not affect the development of A10 in either males or females. Thus, the major homeotic transformation caused by exd appears to be restricted to the female region of disc, that is, to abdominal segment A8. The transformation of $\mathrm{A} 8$ is anterior-ward, similar to the effect of exd in A6 and A7.

Flies mosaic for the hypomorphic exd EM5 allele show only a subset of the homeotic transformations observed with exd $d^{X P 11}$ mosaics. Abdominal segments A1-A5 are unaffected and clones within A6 most often retain their appropriate identity; they are transformed toward A5 in about one-third of the cases (Fig. 4). In contrast, exd ${ }^{E M 5}$ clones within A7 are always transformed anteriorly toward A6, as evidenced by their differentiation into a tergite lacking trichomes (Fig. 4F). In the genitalia, exdEM5 and exd $d^{X 11}$ clones also have similar phenotypes; the same transformations are observed in the female eighth tergite and vaginal plate and $e x d^{E M 5}$ gynandromorphs display the same effects on male genitalia.

\section{exd mutations cause homeotic transformations in the head}

The most obvious effect of amorphic exd clones in the head are transformations of the antenna to leg-type structures. Although clones in the proximal antenna are relatively normal, clones in the third antennal segment and arista are transformed toward leg, as evidenced by the presence of bracted bristles and tarsal claws, cuticular structures associated only with legs (Fig. 6A,B). In the gynandromorph mosaics, we could rule out that these antennae are transformed toward the first thoracic (T1) leg because sex combs, a characteristic feature of male T1 legs, are never associated with them. Rather, in several instances a large apical bristle was associated with the antennal leg, indicative of a transformation toward a T2 identity (Fig. 6B).

Another effect of exd on head development is the failure to recover exd cells in certain head structures. exd null cells never give rise to recognizable vibrissae, orbital, postorbital, or palp bristles. Most often these structures are deleted, although sometimes they are replaced by masses of $y f$ tissue of indeterminate identity. For example, among the surviving gynandromorphs, two exd $d^{X 11}$ clones were recovered in the ocellar region and each was associated with the deletion of the postvertical bristle and perturbation of one ocellus. The structures were replaced by clonal tissue of thinner density cuticle that lacked trichomes, reminiscent of genital tissue. In the mitotic recombination analyses, ectopic exd structures are more frequent. We often found a $y f$ outgrowth on the back of the head that had a cuticular texture, pigmentation and density of trichomes reminiscent of the dorsal thorax or notum (Fig. 6C). One $e x d^{X P 11}$ clone was recovered in the

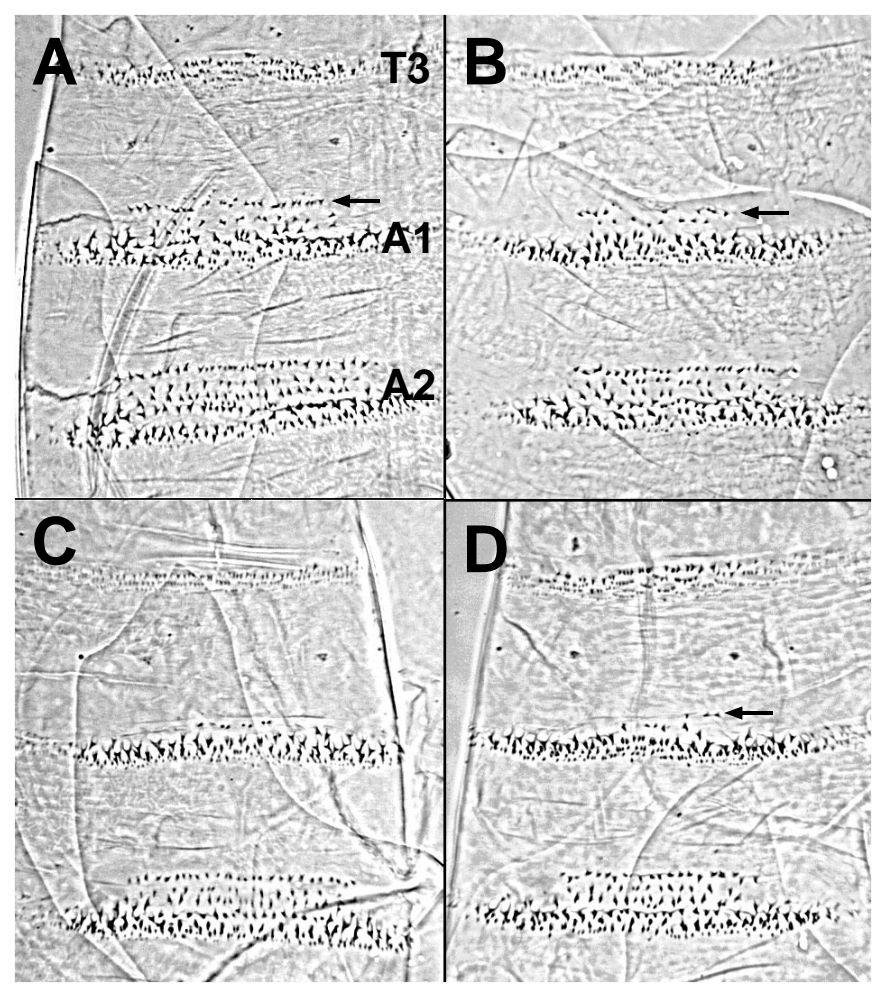

Fig. 3. Hsp70-induced exd expression suppresses the exd embryonic cuticular phenotype. Ventral denticle pattern of first instar larvae. The segments shown are T3, A1, and A2. (A) exd ${ }^{X P 11}$ mutant embryo, showing the clear transformation of A1 to A2 as evidenced by the extra row of denticles (arrow). (B) $e x d^{X P 11} H S$ :exdl embryo raised at $18^{\circ} \mathrm{C}$. Note that $\mathrm{A} 1$ is partially rescued as there are fewer extra denticles (arrow). (C) $e x d^{X P 11} H S$ : exd 3 and (D) $e x d^{X P 11}$ HS:exdl embryos heat-shocked at the onset of gastrulation. These embryos are effectively rescued as only a couple of ectopic denticles remain in $\mathrm{A} 1$ (arrow). 
Fig. 4. Homeotic transformations associated with exd clones in the abdomen. exd clones observed in the tergites of gynandromorphs; identical phenotypes are observed with mitotic clones. In some panels, the clone boundary is designated by a dashed line, the exd mutant tissue starred. Posterior is right. (A) $e x d^{X P 11}$ clone in $\mathrm{A} 1$. In contrast to the surrounding wild-type tissue (arrow), the bristles of this clone are larger and thicker (arrowheads) and the cuticle more darkly pigmented, indicative of a transformation toward A5. (B) exd ${ }^{E M 5}$ clone in A1. This clone is not transformed as the bristles remain small and thin (arrowheads) and the cuticle lightly pigmented. (C) $e x d^{X P 11}$ clone in A4. This clone is transformed towards A5 as evidenced by the dark cuticular pigmentation and sparsely spaced trichomes. (D) exd ${ }^{E M 5}$ clone in A4. The pigmentation of the cuticle and trichome density are appropriate for A4; this clone is not transformed. (E) $e x d^{X P 11}$ clone in A6 and A7. The clone in A6 differentiates trichomes in a region normally devoid of them, and hence is transformed toward A5. In A7 a tergite devoid of trichomes develops, even though the clonal
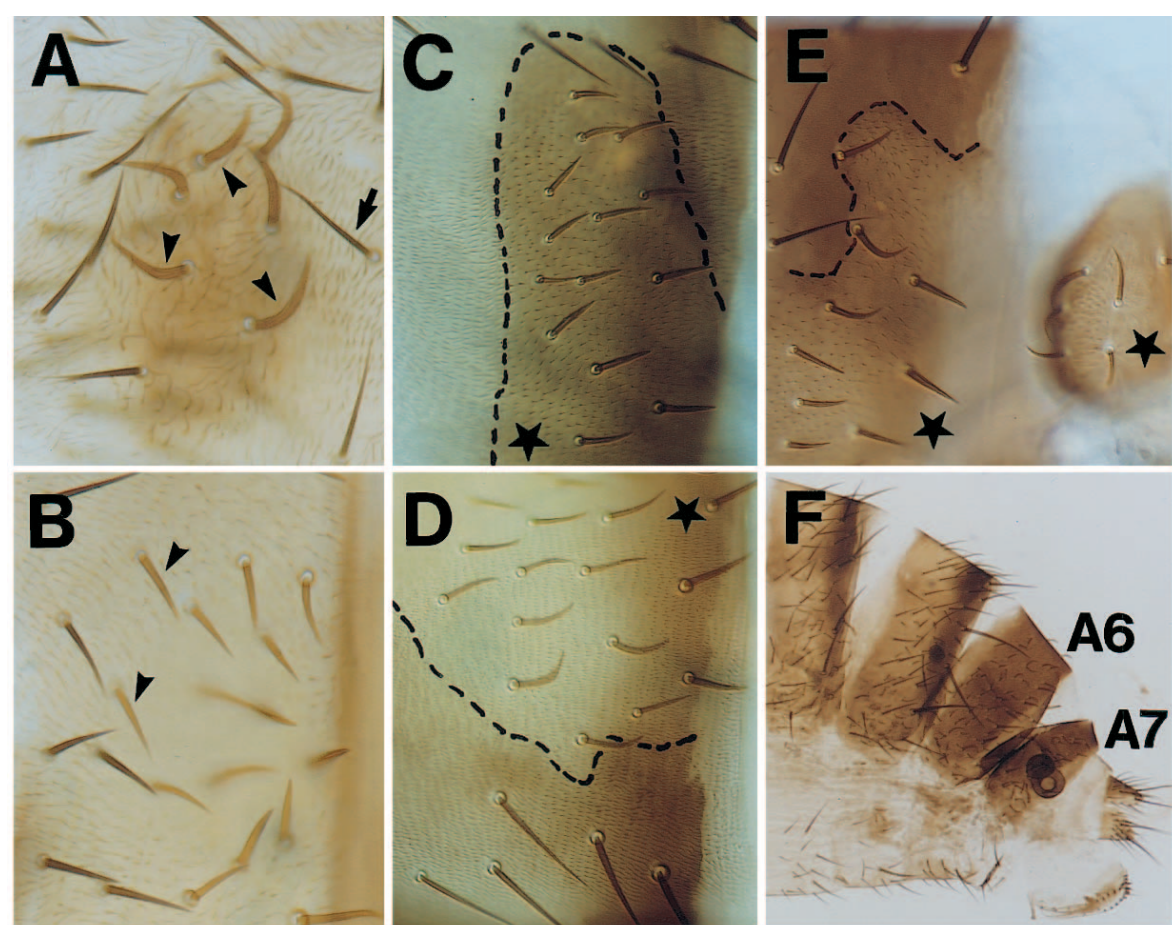

tissue is genotypically male, and thus the clone is transformed toward A6. Sometimes clones within A7 are transformed toward A5. (F) exd ${ }^{E M 5}$ clone in the abdomen. Both A6 and A7 are completely composed of mutant tissue; note that a seventh tergite develops.

labial palp of the proboscis (Fig. 6D,E). This mutant tissue is transformed toward leg, as the bristles within the clone have bracts, found normally only on distal leg structures. The labial disc derivative in the head also shows a reduced frequency of clones; clones survive only in the prementum region of the proboscis where they form protrusions of tissue with ectopic bristles.

In contrast to the limited regions of the head in which exd $\mathrm{XP11}^{\mathrm{P}}$ clones could be recovered, exd ${ }^{E M 5}$ clones in gynandromorphs could encompass any region of the head, to the extent that half of the fly head could be mutant for exd ${ }^{E M 5}$ (Fig. $6 \mathrm{~F})$. In the antenna, exd clones cause a size reduction and slight thickening of the arista (Fig. 6F), which may indicate a partial transformation toward leg. Similar effects are observed in the smaller mitotic recombination clones. Clones in and near the ocellar region are associated with the loss of the ocellar and postvertical bristles (Fig. 6F). Occasionally, clones near the vertical bristle are associated with ectopic bristles like those seen in $\operatorname{exd} d^{X 11}$ clones, and in one case the adjacent occipital region was reduced. Clones are recovered at a reduced frequency in the region of the vibrissae; in those recovered, the large vibrissal bristles are deleted (Fig. 6F). Clones in the cuticular structures derived from the labial disc are normal.

Fig. 5. Homeotic transformations associated with exd clones in the genitalia. Posterior is left. (A) exd null mitotic clones in A8 are transformed anteriorly. The tergite in this female is larger than the normal A8 tergite and heavy bristles characteristic of more anterior segments are present (arrowhead). (B) exd null clones in A9 can transform this segment to a more anterior fate. Normally A9 does not develop in females; here A9 is clearly present (arrowhead). (C) An exd null clone in a gynandromorph. The male genitalia and analia are internalized (arrowhead).

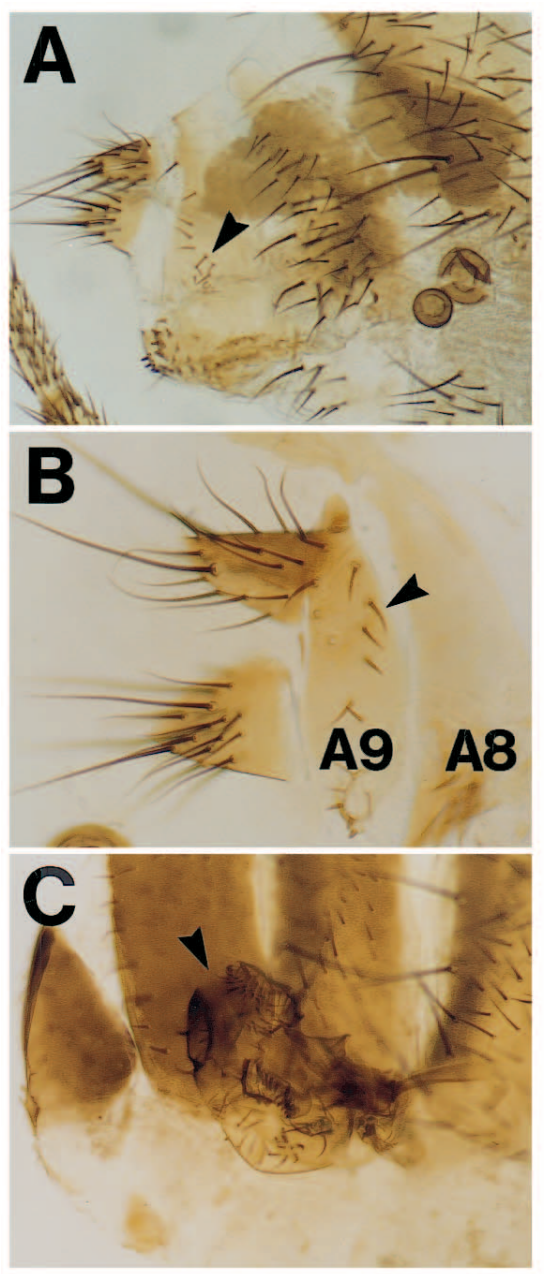




\section{A proximal-distal sensitivity to exd during leg development}

In the thorax, exd mutant tissue derived from the notal region of the wing disc and from the humeral disc is normal, although clone survival is reduced (Table 3 ). The only occasional effect is on the spacing of bristles, which seems to be decreased in mutant clones.

By contrast, exd dramatically affects the development of the legs. Since the frequency of clones in the legs of gynandromorphs was low (Table 2) and they gave similar, if not identical, phenotypes to mitotic clones, only mitotic exd clones will be discussed in detail. Interestingly, the phenotype of exd clones is different depending on whether the clone is located distally or proximally in the leg (Fig. 7). Clones of cells mutant for either the null exd $d^{X 11}$ or the hypomorphic exd $d^{E M 5}$ allele survive and participate in normal patterning of distal tarsal regions of the leg. In contrast, clones located in proximal regions either do not survive, grossly distort pattern and reduce leg segment size, or make ectopic clusters of bristles in regions of the leg normally devoid of bristles (Figs 7, 8). The recovery of clones is graded along the proximal-distal axis and seems to depend on the strength of the allele (Fig. 7). One point that deserves note is that the segmental identities of mutant legs are not affected. For example, a clone in the second thoracic leg can include the apical bristle, a structure characteristic of this leg. Thus, although the pattern of proximal leg segments is distorted, homeotic transformation of proximal leg tissue to another segmental identity (i.e. leg to antenna or leg to genitalia), or transformation to more distal leg fates, is not observed.

A possible proximal-distal bias in the requirement for exd activity is also revealed in non-mosaic animals mutant for the hypomorphic allele. exd ${ }^{E M 5}$ mutants normally die during larval stages. However, if the maternal component of exd is increased, occasional pharate adults are obtained which can be dissected from the pupal case. These flies lack proximal leg
Fig. 6. exd clones in adult heads. (A) exd null clone in the antenna and arista. The clonal tissue is transformed toward leg (arrowheads). The wildtype antenna (a) and arista (r) are designated. The vibrissal bristles are also highly disorganized. (B) Higher magnification of the clone in A showing the distal claw (arrow) and the large apical bristle (arrowhead) indicative of T2 identity. (C) exd null clone protruding from the back of the head (arrowhead). The clonal tissue is darkly pigmented with heavy bristles. (D) $e x d^{X P 11}$ clone in the proboscis (arrowhead). The bristles of this clone have bracts, shown in $\mathrm{E}$ (arrowhead), cuticular structures associated only with leg bristles. (F) Hypomorphic exd $d^{E M 5}$ clone making up half of a gynandromorph head (on right). The arista is shortened and appears thickened (arrowhead) compared to the wild type. The ocellar (oc), postvertical (pv) and large vibrissal (v) bristles are absent.
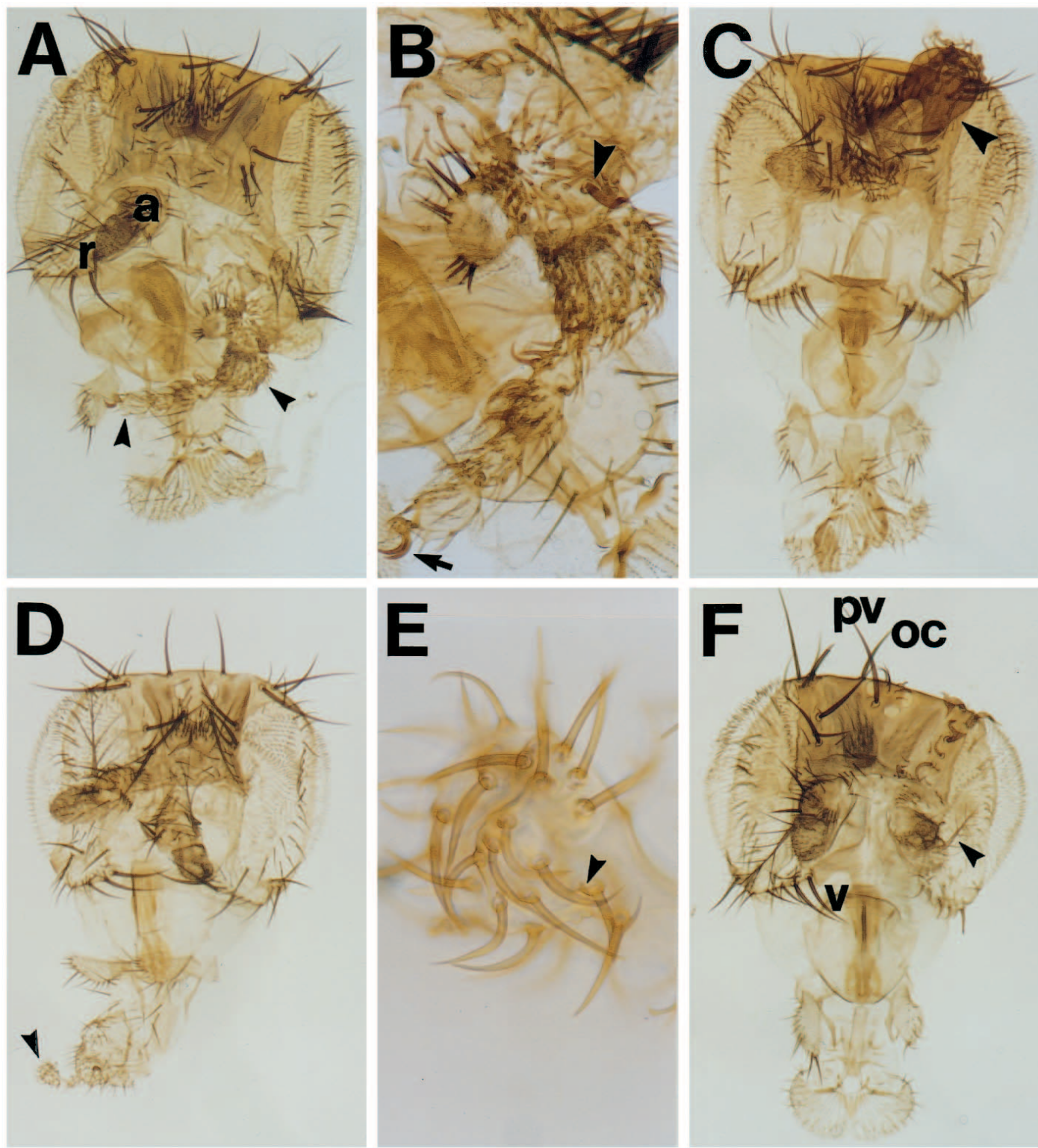
structures, while distal ones are normal. This phenotype is more easily visualized in $e x d^{E M 5}$ gynandromorphs (Fig. 8A). The coxa and trochanter are absent, while the femur and tibia are reduced in length. Distal structures, the tarsal segments, remain unaffected.

To understand further this phenotype, and to determine whether exd may be involved in establishing proximal-distal positional values in the leg primordia, we used various enhancer trap lines as molecular markers of positional values in the leg imaginal discs and examined their expression patterns in discs from exd ${ }^{E M 5}$ mutant third instar larvae. Normally, teashirt is expressed in a ring filling the coxa and trochanter segments, and in the peripodial membrane (Fig. 8B; Cohen, 1993). In exd ${ }^{E M 5}$ discs this pattern is unaltered (Fig. 8C). Expression patterns of additional molecular markers such as odd-skipped, expressed in a ring in each leg segment, and apterous, expressed in the fourth tarsal segment (Cohen et al., 1992), remain normal in $\operatorname{exd}^{E M 5}$ discs (data not shown). Thus, although the coxa and trochanter are deleted in the adult cuticular structures of exd ${ }^{E M 5}$ mutant flies, the establishment of positional values in the leg primordia remains unaffected.

\section{Ubiquitous expression of exd does not alter segmental identities}

Our analysis of exd clones has indicated that loss of exd in certain regions of the animal results in homeotic transformations. Intriguingly, in the abdomen, the loss of exd results in the transformation of A1-A4 and A6-A9 to an A5/A6 segmental identity, precisely those segments in the embryo that have the lowest levels of exd expression. To determine whether the modulated expression of exd during embryogenesis is essential for normal patterning in the adult, we tested whether increased levels of exd could alter segmental identities in the abdomen or elsewhere in the fly. We used the $h s p 70$ promoter to drive high and ubiquitous exd expression throughout development and examined the effects.
First instar larvae transgenic for HS:exd were heat-shocked for 1 hour at $37^{\circ} \mathrm{C}$ every day until the adult flies eclosed. HS:exd flies treated in this manner are viable and do not display any homeotic transformations or other developmental aberrations. We also attempted to induce persistent ubiquitous expression of exd by placing $H S$ :exd larvae at $33^{\circ} \mathrm{C}$ until the completion of pupal development. Although the HS:exd and the white control flies do not eclose, dissection of the HS:exd flies from their pupal cases revealed that this treatment does not alter segmental identity. The fact that these HS: exd constructs are capable of rescuing exd embryos (see above) indicates that they make functional exd protein upon heatshock. Thus, although the loss of exd can result in homeotic transformations, ubiquitous expression of exd does not appear to have morphological consequences.

\section{DISCUSSION}

The studies presented here demonstrate that exd, like the homeotic selector genes, not only establishes segmental identities during embryonic development, but also during adult morphogenesis. Consistent with its genetic requirement, exd is expressed throughout embryogenesis and in imaginal discs, the primordia of many adult cuticular structures (Fig. 1; Rauskolb et al., 1993). We show that in the adult, exd clones often do not display their appropriate segmental identity, adopting instead a morphology characteristic of another segment. Clones of a hypomorphic exd allele displayed a subset of the phenotypes observed with a null allele, presumably reflecting differential requirements for exd activity in different cell fate decisions. Molecular characterization of the exd alleles revealed that, while exd null mutations would result in a truncated protein, the two hypomorphic mutations contain missense mutations within the exd homeodomain, thereby perhaps affecting the ability of exd to bind to its target sequences.

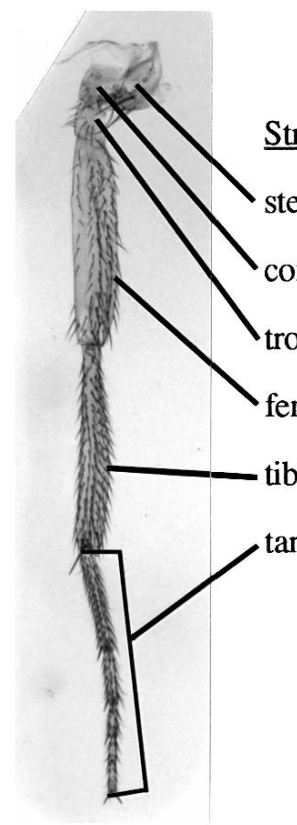

\begin{tabular}{lll} 
& \multicolumn{2}{l}{ \# of Clones/Leg } \\
$\underline{\nu w f}$ & $\underline{e x d}^{E M 5}$ & $\underline{e x d}^{X P 11}$ \\
0.21 & 0 & 0.04 \\
0.83 & 0.66 & 0.07 \\
0.74 & 0.82 & 0.17 \\
0.98 & 1.20 & 0.41 \\
0.85 & 0.93 & 0.48 \\
0.62 & 0.80 & 0.31
\end{tabular}

\# of Clones/Leg

Structure

sternopleura

coxa

ochanter

femur

tibia

arsal segments

\begin{tabular}{|c|c|c|}
\hline \multirow[b]{2}{*}{$\underline{\nu w f}$} & \multicolumn{2}{|c|}{$\%$ Defective } \\
\hline & $\underline{e x d}^{E M 5}$ & $\underline{e x d}^{X P 11}$ \\
\hline $0 \%$ & N.A. & $100 \%$ \\
\hline $0 \%$ & $100 \%$ & $100 \%$ \\
\hline $3 \%$ & $98 \%$ & $100 \%$ \\
\hline $4 \%$ & $81 \%$ & $73 \%$ \\
\hline $2 \%$ & $2 \%$ & $58 \%$ \\
\hline $7 \%$ & $7 \%$ & $0 \%$ \\
\hline
\end{tabular}

\% Defective $\underline{\operatorname{exd}}^{E M 5} \quad \underline{\operatorname{exd}}^{\mathrm{XP11}}$ $00 \%$

$58 \%$

$0 \%$

Fig. 7. Recovery of exd mitotic clones in legs. The frequency at which clones were observed in different segments of clone-carrying legs (no. of clones/leg). The frequency with which these clones resulted in abnormal cuticular patterning or distortion and kinking of the leg segment is given as \% defective. The sternopleura is proximal; the tarsal segments are distal. ywf clones serve as controls. 


\section{exd is necessary but not sufficient to establish segmental identities}

Clones of exd null mutant cells in the abdomen always adopt an A5 or A6 identity, regardless of their segmental location. Normally, abdominal segmental identities are specified by the BX-C homeotic selector genes Ultrabithorax (Ubx), abdominal-A (abd-A), and Abdominal-B (Abd-B) (reviewed by Duncan, 1987). Each of the first eight abdominal segments (A1-A8) is specified by unique combinations and levels of expression of these three genes. Specific levels of embryonic homeotic gene expression correlate with specific morphological consequences in the adult. The fifth and sixth abdominal segments arise from cells expressing high levels of $a b d-A$ and low levels of $A b d-B$ (Celniker et al., 1989; DeLorenzi and Bienz, 1990; Karch et al., 1990; Macias et al., 1990; Boulet et al., 1991). Clearly these genes do not require exd in order to specify the identity of A5, as exd clones within A5 always retain their appropriate segmental identity. By contrast, correct identity specification of A1-A4 and $\mathrm{A} 6-\mathrm{A} 8$ requires both the $\mathrm{BX}-\mathrm{C}$ genes and exd. In the absence of exd these segments are all transformed toward A5/A6. We do not think that these adult transformations result from selector gene mis-expression, since the homeotic selector genes are expressed normally in exd mutant embryos in a variety of different tissues (Peifer and Wieschaus, 1990a; Rauskolb and Wieschaus, 1994), but this possibility cannot be excluded. Nor can the homeotic genes simply be inactive; a deficiency for the $\mathrm{BX}-\mathrm{C}$ results in the transformation of all abdominal segments toward a second thoracic identity (Lewis, 1978). Instead, we postulate that in the absence of exd the homeotic selector proteins inappropriately regulate the expression of genes involved in adult morphogenesis, analogous to the mis-regulation of target genes by the homeotic proteins in exd mutant embryos (Rauskolb and Wieschaus, 1994). Our results argue that during imaginal development the homeotic genes $U b x, a b d-A$, and $A b d-B$ all require exd in order to correctly regulate their downstream targets.

Notably, exd expression levels in the abdomen of the late embryo are graded, with the lowest levels in A5 and A6 (Fig. 1; Rauskolb et al., 1993). Although exd clones in the abdomen are transformed toward the segments with the lowest levels of exd, the actual level of exd expression does not appear to be instructive. Induction of high ubiquitous exd expression does not alter segmental morphology, suggesting that different exd levels may play, at most, only a subtle role in dictating different segmental identities. Nonetheless, exd expression levels do reflect the differential requirement for exd in each of the segments. A differential requirement for exd activity was also observed with our gynandromorphs, as the head and thorax, those regions in the embryo with the highest levels of exd expression, are particularly sensitive to the loss of exd.

\section{exd functions in the head}

Clones of exd in the head result in homeotic transformations and phenotypes reminiscent of those observed with mutations in some ANT-C genes, suggesting that exd may also act together with these genes to specify segmental identities. For example, a clone of exd tissue in the labial palp gave rise to leg tissue, which is similar to, albeit less complete than, the transformation observed with mutations in proboscipedia (Kaufman, 1978). Furthermore, exd clones often result in deletion of head structures, which has also been associated with mutations in Deformed (Merrill et al., 1987). Taken together, these results imply that exd may also interact with proboscipedia and Deformed in establishing segmental identities.

Although exd acts as a cofactor of the homeotics in the specification of many segmental identities, the specification of the antenna and arista by exd must occur differently. In the absence of $e x d$, both structures are transformed toward leg. No known homeotic selector gene is expressed in the region of the eye-antennal imaginal disc that will give rise to the antenna and arista. However, if Antp or $U b x$ is ectopically expressed in the eye-antennal disc, these structures are transformed toward leg (Frischer et al., 1986; Jorgensen and Garber, 1987; Schneuwly et al., 1987; Gibson and Gehring, 1988; Mann and Hogness, 1990). Thus, exd may negatively regulate the expression of a homeotic selector gene in the eyeantennal imaginal disc. Alternatively, exd may function independently of the homeotic selector genes in the antenna and arista, analogous to the independent regulation of a downstream gene by exd in the visceral mesoderm (Rauskolb and Wieschaus, 1994). Thus, in the eye-antennal disc, exd may independently repress the expression or function of leg promoting genes, similar to how Antp acts in the leg imaginal discs to repress the function of head-promoting genes (Struhl, 1981).

\section{Differential sensitivities to exd during leg development}

exd is required for the correct patterning of proximal leg structures but not distal structures. Although it is clear that there is a differential proximal-distal sensitivity to $e x d$, this sensitivity is not reflected in an underlying graded expression pattern of exd; exd transcripts are uniformly distributed in leg imaginal discs (Fig. 1). Furthermore, the absence of exd does not affect the proximal-distal nature of a group of cells (Fig. 8 ), but rather whether these cells will differentiate into an appropriate leg structure. Although homeotic transformations were not observed with exd leg clones, it is still possible that their identity is altered in such a way that they are prevented from contributing to the normal pattern of the leg. In this regard, it is interesting to compare exd clones to Antp clones in the first and third legs. Like exd clones, abnormal Antp clones are associated with atypical cuticular patterns and an absence of leg structures, giving the leg a truncated appearance (Struhl, 1981). In addition, in the second leg, proximal Antp clones are transformed toward antenna, while distal clones develop normally (Struhl, 1981, 1982). Together, the analyses of exd and Antp clones suggest that proximal leg structures are inherently more sensitive to alterations in homeotic gene function. Thus, the effects of exd on leg development may again be consistent with alterations in homeotic gene activity.

\section{exd acts in concert with many homeotic selector genes}

We previously showed that exd acts together with the homeotic 
Fig. 8. exd affects the development of legs. (A) $e x d^{E M 5}$ gynandromorph clone in the first thoracic leg. The proximal leg segments, the coxa (co) and trochanter (tr) are absent, and the femur (fe) and tibia (ti) are abnormal. The distal tarsal (ta) segments are normal. Sex-combs are found on the exd mutant leg (arrow) because the genotype of this tissue is male, whereas the wild-type leg tissue is female. (B) teashirt enhancer trap expression in wild-type and (C) $e^{E} d^{E M 5}$ mutant third instar leg imaginal discs. In both discs, expression is observed in the primordia of the coxa and trochanter segments. (D) exd null mitotic clone in a leg. The patterning of the femur (arrowhead) is severely disrupted. (E) Higher magnification of the clone in D. (F) Abnormal exd null clone in the coxa (arrowhead), also shown at high magnification (inset).
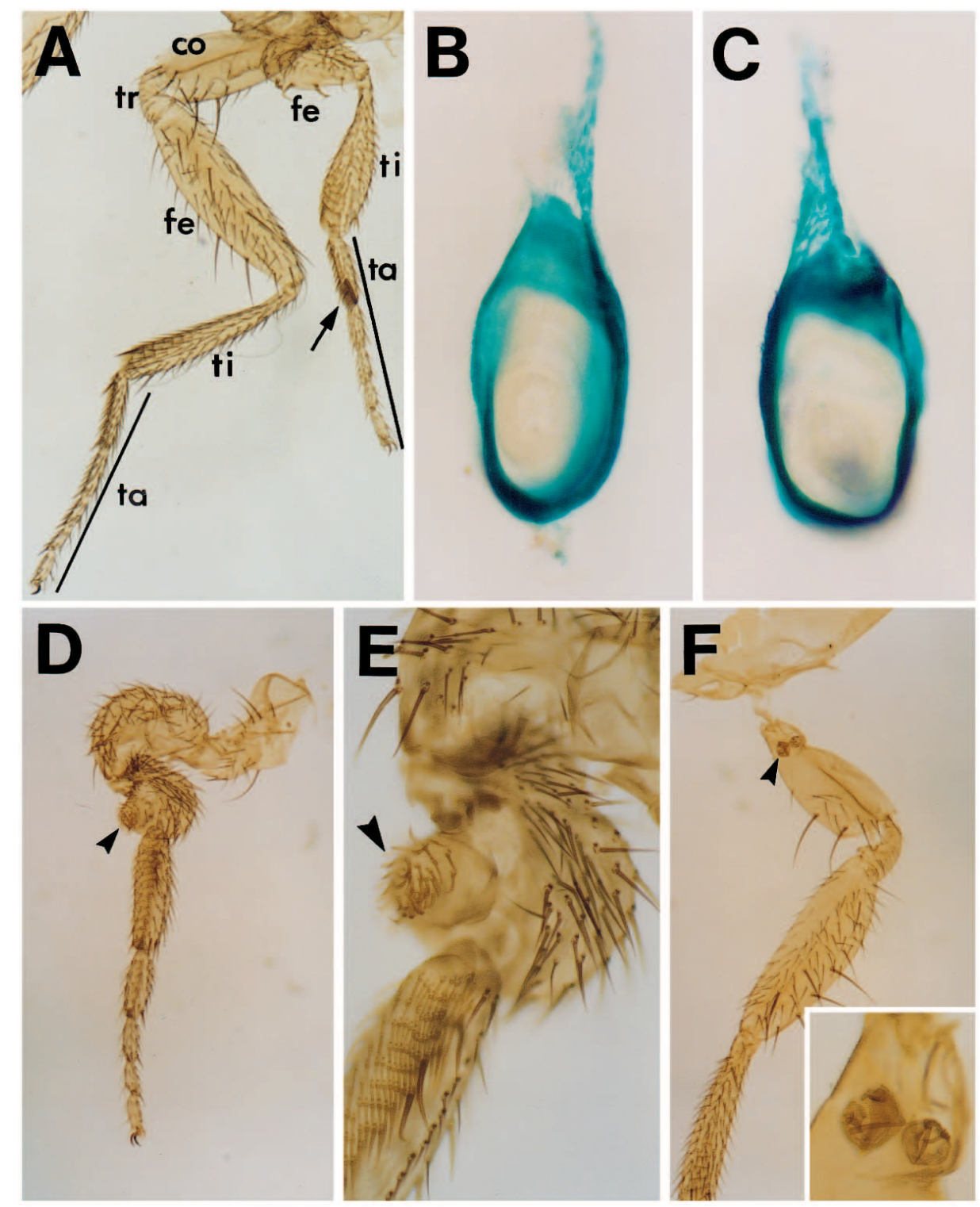

selector proteins ANTP, UBX, and ABD-A in the regulation of genes that execute morphogenetic events in the embryo (Peifer and Wieschaus, 1990; Rauskolb and Wieschaus, 1994). In the absence of exd, the activity of these homeotic selector proteins is altered such that they no longer appropriately regulate their target genes, resulting in altered morphogenesis. In vitro studies have provided a molecular model for these in vivo findings. exd and the homeotic selector proteins cooperatively bind DNA; exd alters the DNA-binding specificity of UBX and ABD-A (Chan et al., 1994; van Dijk and Murre, 1994). Although no such interactions were found between exd and ANTP on the target DNA used in these in vitro studies, our previous studies strongly suggested that exd modulates ANTP function (Rauskolb and Wieschaus, 1994). Our results presented here suggest that $e x d$ also affects the morphological outcome of proboscipedia, Deformed, Ubx, abd-A, and $A b d-B$ activities during adult development. Given the overlap in the expression of and requirement for exd and the homeotic selector genes, exd appears to be an indispensable factor that cooperates with most of the homeotic selector proteins in many cell fate decisions throughout development.

We especially thank John Scott for his initial observations on exd and Joan Shields for valuable technical assistance in analyzing the exd mutations. We thank Alisa Katzen for generously supplying us with exd alleles, Stephen Cohen, Ken Irvine, and Stephen Kerridge for enhancer trap lines, and Susan Zusman for the stock carrying $\operatorname{In}(1) w^{v C}$. We also thank Richard Mann and Yash Hiromi for heatshock vectors. Many thanks to Ken Irvine for improving this manuscript. This research was funded by National Institutes of Health grant 5RO1HD22780 to E. W. and by a grant from the Searle Scholars program to M. P.

\section{REFERENCES}

Botas, J. (1993). Control of morphogenesis and differentiation by HOM/Hox genes. Curr. Opin. Cell Biol. 5, 1015-1022. 
Boulet, A. M., Lloyd, A. and Sakonju, S. (1991). Molecular definition of the morphogenetic and regulatory functions and the cis-regulatory elements of the Drosophila Abd-B homeotic gene. Development 111, 393-405.

Bryant, P. J. (1978). Pattern formation in imaginal discs. In The Genetics and Biology of Drosophila, (ed. M. Ashburner and T. W. F. Wright), pp. 229-289. New York: Academic Press.

Celniker, S. E., Keelan, D. J. and Lewis, E. B. (1989). The molecular genetics of the bithorax complex of Drosophila: characterization of the products of the Abdominal-B domain. Genes Dev. 3, 1424-36.

Chan, S.-K., Jaffe, L., Capovilla, M., Botas, J. and Mann, R. S. (1994). The DNA binding specificity of Ultrabithorax is modulated by cooperative interactions with extradenticle, another homeoprotein. Cell 78, 603-615.

Cohen, B., McGuffin, M. E., Pfeifle, C., Segal, D. and Cohen, S. M. (1992). apterous: a gene required for imaginal disc development in Drosophila encodes a member of the LIM family of developmental regulatory proteins. Genes Dev. 6, 715-729.

Cohen, S. M. (1993). Imaginal disc development. In The Development of Drosophila melanogaster (ed. M. Bate and A. Martinez Arias), pp. 747-841. Cold Spring Harbor NY: Cold Spring Harbor Laboratory Press.

DeLorenzi, M. and Bienz, M. (1990). Expression of Abdominal-B homeoproteins in Drosophila embryos. Development 108, 323-329.

Duncan, I. (1987). The bithorax complex. Anпи. Rev. Genet. 21, 285-319.

Fasano, L., Röder, L., Coré, N., Alexandre, E., Vola, C., Jacq, B. and Kerridge, S. (1991). The gene teashirt is required for the development of Drosophila embryonic trunk segments and encodes a protein with widely spaced zinc finger motifs. Cell 64, 63-79.

Frischer, L. E., Hagen, F. S. and Garber, R. L. (1986). An inversion that disrupts the Antennapedia gene causes abnormal structure and localization of RNAs. Cell 47, 1017-1023.

Gibson, G. and Gehring, W. J. (1988). Head and thoracic transformation caused by ectopic expression of Antennapedia during Drosophila development. Development 102, 657-675.

Irvine, K. D., Helfand, S. L. and Hogness, D. S. (1991). The large upstream control region of the Drosophila homeotic gene Ultrabithorax. Development 111, 407-424.

Jorgensen, E. M. and Garber, R. L. (1987). Function and misfunction of the two promoters of the Drosophila Antennapedia gene. Genes Dev. 1, 544555 .

Karch, F., Bender, W. and Weiffenbach, B. (1990). abdA expression in Drosophila embryos. Genes Dev. 4, 1573-1587.

Karch, F., Weiffenbach, B., Peifer, M., Bender, W., Duncan, I., Celniker, S., Crosby, M. and Lewis, E. B. (1985). The abdominal region of the bithorax complex. Cell 43, 81-96.

Katzen, A. L. (1990). Proto-oncogenes in Drosophila: Molecular and Genetic Analysis. Ph.D. dissertation Thesis, University of California, San Francisco.

Kaufman, T., Seeger, M. A. and Olsen, G. (1990). Molecular and genetic organization of the Antennapedia gene complex of Drosophila melanogaster. In Advances in Genetics (ed. T. R. F. Wright), pp. 309-362. San Diego: Academic Press.

Kaufman, T. C. (1978). Cytogenetic analysis of chromosome 3 in Drosophila melanogaster: Isolation and characterization of four new alleles of the proboscipedia $(\mathrm{pb})$ locus. Genetics $\mathbf{9 0}, \mathbf{5 7 9 - 5 9 6 .}$

Lewis, E. B. (1978). A gene complex controlling segmentation in Drosophila. Nature 276, 565-70.

Lindsley, D. L. and Zimm, G. G. (1992). The Genome of Drosophila melanogaster. San Diego, California: Academic Press.
Macias, A., Casanova, J. and Morata, G. (1990). Expression and regulation of the abd-A gene of Drosophila. Development 110, 1197-1207.

Mann, R. S. and Hogness, D. S. (1990). Functional dissection of Ultrabithorax proteins in D. melanogaster. Cell 60, 597-610.

Merrill, V. K. L., Turner, F. R. and Kaufman, T. C. (1987). A genetic and developmental analysis of mutations in the Deformed locus in Drosophila melanogaster. Dev. Biol. 122, 379-395.

Monica, K., Galili, N., Nourse, J., Saltman, D. and Cleary, M. L. (1991). PBX2 and PBX3, new homeobox genes with extensive homology to the human proto-oncogene PBX1. Mol. Cell. Biol. 11, 6149-6157.

Peifer, M. and Wieschaus, E. (1990a). Mutations in the Drosophila gene extradenticle affect the way specific homeo domain proteins regulate segmental identity. Genes Dev. 4, 1209-1223.

Peifer, M. and Wieschaus, E. (1990b). The segment polarity gene armadillo encodes a functionally modular protein that is the Drosophila homolog of human plakaglobin. Cell 63, 1167-1178.

Rauskolb, C., Peifer, M. and Wieschaus, E. (1993). extradenticle, a regulator of homeotic gene activity, is a homolog of the homeobox-containing human proto-oncogene pbxl. Cell 74, 1101-1112.

Rauskolb, C. and Wieschaus, E. (1994). Coordinate regulation of downstream genes by extradenticle and the homeotic selector proteins. EMBO J. 13, 3561-3569.

Sanchez-Herrero, E., Vernos, I., Marco, R. and Morata, G. (1985). Genetic organization of Drosophila bithorax complex. Nature 313, 108-113.

Schneuwly, S., Klemenz, R. and Gehring, W. J. (1987). Redesigning the body plan of Drosophila by ectopic expression of the homoeotic gene Antennapedia. Nature 325, 816-818.

Schüpbach, T., Wieschaus, E. and Nöthiger, R. (1978). The embryonic organization of the genital disc studied in genetic mosaics of Drosophila melanogaster. Roux's Arch. Dev. Biol. 185, 249-270.

Struhl, G. (1981). A homoeotic mutation transforming leg to antenna in Drosophila. Nature 292, 635-8.

Struhl, G. (1982). Genes controlling segmental specification in the Drosophila thorax. Proc. Natl. Acad. Sci. USA 79, 7380-4.

van Dijk, M. A. and Murre, C. (1994). extradenticle raises the DNA binding specificity of homeotic selector gene products. Cell 78, 617-624.

Wieschaus, E. and Noell, E. F. (1986). Specificity of embryonic lethal mutations in Drosophila analysed in germ line clones. Wilhelm Roux's Arch. Dev. Biol. 195, 63-73.

Wieschaus, E., Nüsslein-Volhard, C. and Jürgens, G. (1984). Mutations affecting the pattern of the larval cuticle in Drosophila melanogaster. III Zygotic loci on the X chromosome and the fourth chromosome. Wilhelm Roux's Arch. Dev. Biol. 193, 267-282.

Wieschaus, E., Perrimon, N. and Finkelstein, R. (1992). orthodenticle activity is required for the development of medial structures in the larval and adult epidermis of Drosophila. Development 115, 801-811.

(Accepted 9 August 1995)

\section{Notes added in proof}

The accession number for the excl genomic sequence is U33747.

Similar results have been described by González-Crespo, S. and Morata, G. (1995). Control of Drosophila adult pattern by extradenticle. Development 121, 2117-2125. 